\title{
KONTRIBUSI PENERAPAN METODE PEMBELAJARAN DAN AKTIVITAS BELAJAR TERHADAP HASIL BELAJAR FIKIH SISWA MADRASAH TSANAWIYAH NEGERI TANAH JAWA KABUPATEN SIMALUNGUN
}

\author{
Budi Suemdi \\ Guru MTsN Tanah Jawa Simalungun
}

\begin{abstract}
This study aims to find out and emphasize: (1) the positive and significant contribution of the application of learning methods to Jurisprudence learning outcomes, (2) the positive and significant contribution of learning activities to Jurisprudence learning outcomes, and (3) the positive and significant contribution of the application of learning methods and activities learn together about the results of Jurisprudence learning. This research is quantitative research with correlation research methods. The population in this study were all students of class VIII consisting of 6 classes with a total of 172 . Samples totaling $35 \%$ of students totaling 205 is 71.75 were rounded up to 72 students taken randomly. The data collection instruments used were questionnaires and tests. The data analysis used is correlation and regression. The research findings show: (1) there are positive and significant contributions between the application of learning methods and learning outcomes with a correlation number 0.354 with the regression line equation $\hat{Y}=71.60+0.23 \mathrm{X}_{1}$, (2) there are positive and significant contributions between learning activities and outcomes study with a correlation number of 0.473 with the regression line equation $\hat{Y}=$ $68.96+0.28 \mathrm{X}_{2}$. and (3) there are positive and significant contributions between the application of learning methods and learning activities with learning outcomes with a correlation number of 0.549 with the regression line equation $\hat{Y}=138.80+0.18 \mathrm{X}_{1}+0.25 \mathrm{X}_{2}$. Effective contribution of the variable of the application of learning methods to learning outcomes is $9.90 \%$, while the effective contribution of the learning activity variable to learning outcomes is $20.00 \%$
\end{abstract}

\section{Keyword: Learning Methods, Learning Activities and Learning Outcomes}

\section{PENDAHULUAN}

Kualitas pembelajaran dapat dilihat dari segi proses dan dari segi hasil. Dari segi proses, pembelajaran dikatakan berkualitas dan berhasil jika seluruhnya atau setidak-tidaknya sebagian besar siswa terlibat secara aktif, baik fisik, mental maupun sosial dalam proses pembelajaran. Selain itu, proses pembelajaran yang berkualitas juga menunjukkan kegairahan 
belajar yang tinggi, semangat (motivasi) belajar yang besar, dan adanya rasa percaya diri pada siswa. Dengan kata lain pembelajaran dikatakan berkualitas dan berhasil apabila terjadi perubahan perilaku yang positif pada diri siswa seluruhnya atau sekurang-kurangnya sebagian besar.

Metode pembelajaran yang diterapkan dalam pembelajaran FIkih diperkirakan akan berpengaruh terhadap proses belajar siswa dalam upaya mencapai hasil belajar. Dalam hal ini salah satu tugas pendidik atau guru adalah menciptakan suasana pembelajaran yang dapat membuat siswa untuk senantiasa belajar dengan baik dan bersemangat. Suasana pembelajaran yang demikian akan berdampak positif dalam pencapaian prestasi belajar yang optimal. Guru sebaiknya memiliki kemampuan dalam memilih metodembelajar pembelajaran yang tepat.

Penerapan metode pembelajaran yang tidak tepat akan menimbulkan kejenuhan bagi siswa dalam menerima materi yang disampaikan sehingga materi kurang dapat dipahami yang akan mengakibatkan siswa menjadi apatis. Oleh karena itu guru tidak hanya dituntut memiliki pengetahuan dan kemampuan mengajar, tetapi juga mewujudkan kompleksitas peran sesuai dengan tugas dan fungsi yang diembannya secara kreatif (Agung, 2010).

Guru berperan sebagai desainer pembelajaran tidak dapat diabaikan baik dalam hal memilih metode pembelajaran yang sesuai untuk para siswanya. Hal ini diungkapkan mengingat pentingnya peranan guru dalam menentukan pencapaian tujuan pembelajaran yang pada akhirnya dapat meningkatkan hasil belajar siswa. Hal ini disebabkan pembelajaran yang selalu menuntut siswa untuk menguasai materi ajar tanpa melatih siswa untuk menggunakan pikirannya sebagai alat komunikasi lisan atau tulis untuk meningkatkan pengetahuan, sikap dan ketrampilannya. Guru telah cukup puas apabila siswanya sudah dapat menguasai materi ajar dan tidak terlalu memberi perhatian terhadap kemampuan siswa dengan baik dan benar dalam bahasa lisan dan tulisan. Untuk melaksanakan pembelajaran yang maksimal perlu diperhatikan berbagai faktor diantaranya kajian terhadap materi ajar, karakteristik siswa, media dan sebagainya. Di samping itu yang tidak kalah pentingnya adalah perlu dirancang suatu metode pembelajaran yang dapat meningkatkan kemampuan siswa dalam menguasai materi ajar.

Faktor lain yang tak kalah pentingnya adalah aktivitas belajar itu sendiri. Dalam aktivitas-aktivitas belajar yang dilakukan siswa terkandung maksud agar selain untuk penguatan juga menimbulkan sikap positif terhadap pembelajaran Fikih. Bagi seorang guru, melahirkan 
sikap positif merupakan suatu hal yang sangat penting dilakukan untuk semua mata pelajaran, termasuk mata pelajaran Fikih. Karena dengan sikap positif ini akan muncul kecintaan atau rasa suka terhadap mata pelajaran tertentu. Dan secara otomatis rasa suka atau kecintaan terhadap mata pelajaran tertentu akan menimbulkan kegairahan bagi siswa untuk mempelajarinya.

Hal ini berarti aktivitas belajar yang dilakukannya berhubungan dengan mata pelajaran yang ia senangi juga akan meningkat. Misalnya, siswa akan belajar meskipun tidak ada guru di dalam kelas, ia akan mengulang atau mempelajari materi yang sudah atau belum dipelajari meskipun tidak ada yang mengintruksikannya, membuat rangkuman, menggaris bawahi materi-materi yang dianggap penting, menyiapkan peralatan belajar yang akan digunakan keesokan harinya, dan lain sebagainya.

Pemberian tugas biasanya dalam bentuk pekerjaan rumah, yang bertujuan memberikan kesempatan siswa untuk mendapatkan pengertian yang luas tentang topik dan konsep-konsep yang telah dan akan diajarkan di dalam kelas. Dengan ini siswa akan lebih mengetahui kelemahan dalam mempelajari dan memahami materi yang telah diajarkan. Dan dengan adanya pemberian tugas terstruktur tersebut siswa juga tidak akan merasa bosan dalam belajar karena materi pelajaran disampaikan secara berurutan atau terprogram serta menyenangkan sehingga siswa dengan mudah mengerjakan tugas yang dapat menimbulkan pengalaman belajar yang nantinya dapat meningkatkan hasil belajarnya.

\section{KAJIAN TEORETIS}

Metode adalah upaya atau cara si pendidik untuk menyampaikan materi pelajaran kepada peserta didik (Daulay, 2016). Sementara itu Nata (2014) menjelaskan metode adalah cara-cara atau langkah-langkah yang digunakan dalam menyampaikan sesuatu gagasan, pemikiran atau wawasan yang disusun secara sistematik dan terencana serta didasarkan pada teori, konsep dan prinsip tertentu yang terdapat dalam berbagai disiplin ilmu terkait, terutama ilmu psikologi, manajemen dan sosiologi.

Metode adalah cara yang di dalam fungsinya merupakan alat untuk mencapai tujuan (Surakhmad, 1994). Makna metode yang dikemukakan Surakhmad terkandung di dalamnya adalah metode merupakan sarana untuk menemukan, menguji dan menyusun data yang diperlukan bagi pengembangan disiplin ilmu. Maka usaha pengembangan metode itu sendiri merupakan syarat mutlak. Dengan 
demikian harus melalui tinjauan akademik, pengetahuan mengenai metode ini merupakan bagian yang tidak terpisahkan dari keseluruhan disiplin yang bersangkut.

Metode pembelajaran adalah cara-cara atau teknik yang dianggap jitu untuk menyampaikan materi ajar (Prawiradilaga, 2008). Hal senada dengan ini dijelaskan Sanjaya (2014) bahwa metode pembelajaran adalah cara yang digunakan untuk mengimplementasikan rencana yang sudah disusun dalam kegiatan nyata agar tujuan yang telah disusun tercapai secara optimal. Smaldino dkk (2008) memaparkan bahwa metode pembelajaran merupakan proses atau prosedur yang digunakan guru atau instruktur untuk mencapai tujuan atau kompotensi. Pemilihan metode yang tepat dapat membantu siswa mencapai tujuan pembelajaran atau melakukan internalisasi terhadap isi atau materi pembelajaran.

Sudjana (2002) menjelaskan metode pembelajaran adalah cara yang dipergunakan guru dalam mengadakan hubungan dengan siswa pada saat berlangsungnya pengajaran. Dalam interaksi ini guru berperan sebagai penggerak atau pembimbing sedangkan siswa berperan sebagai penerima atau yang dibimbing. Selanjutnya menurut Hasibuan dan Moedjiono (2004) metode pembelajaran adalah alat yang dapat merupakan bagian dari perangkat alat dan cara dalam pelaksanaan suatu pembelajaran yang digunakan untuk mencapai tujuan belajar.

Usman (2002) menjelaskan pengertian metode pembelajaran yaitu suatu cara penyampaian bahan pelajaran untuk mencapai tujuan yang ditetapkan, maka fungsi metode mengajar tidak dapat diabaikan karena turut menentukan berhasil tidaknya suatu proses pembelajaran dan merupakan bagian integral dalam suatu sistem pengajaran. Senada dengan penjelasan Usman, dalam hal ini Djamarah dan Zain (2002) memaparkan bahwa metode pembelajaran adalah strategi pengajaran sebagai alat untuk mencapai tujuan yang diharapkan.

Aktivitas belajar merupakan pengalaman yang harus dimiliki dalam belajar. Karena aktivitas belajar siswa merupakan interaksi siswa dengan objek belajarnya sebagai bentuk kerja nyata dari kegiatan siswa selama proses belajar mengajar berlangsung. Aktivitas merupakan bagian yang penting dari kegiatan siswa selama proses pembelajaran berlangsung.

Slameto (2003) menegaskan bahwa aktivitas belajar adalah kegiatan pembelajaran baik rohani yang menghendaki bekerjanya fungsi pemikiran maupun jasmani yang menghendaki gerakan fungsi otot-otot individu yang belajar. Dalam kegiatan belajar kedua aktivitas tersebut harus selalu 
berkaitan. Piaget dalam Nasution (2005) menyatakan bahwa seorang anak berpikir sepanjang ia berbuat. Jadi tanpa melakukan sesuatu perbuatan siswa belum rasional cara berpikirnya, oleh sebab itu guru hendaknya dapat menciptakan kondisi yang baik sehingga memungkinkan setiap siswa dapat mengembangkan kreativitasnya.

Nasution (2005) menyatakan bahwa makin banyak siswa diberikan aktivitas, maka makin banyak pula mereka menguasai materi yang dilatihkan itu. Pelajaran tidak segera dikuasai hanya dengan mendengar dan membacanya saja tapi perlu kegiatan lain seperti membuat rangkuman, mengadakan tanya jawab atau diskusi dengan teman-teman dan mencoba menjelaskannya kepada orang lain.

Serangkaian studi yang dilakukan Thorndike dan Woodworth sebagaimana dikutip Soetomo (2003), mengemukakan bahwa berlatih untuk tugas tertentu memudahkan belajar di waktu kemudian hanya untuk tugas yang serupa, bukan untuk tugas yang tidak serupa. Hubungan ini dikenal dengan istilah alih latihan dan transfer training. Akibat adanya pembiasaan-pembiasaan dalam belajar maka apa yang dipelajari tersebut lebih bermakna dalam ingatan dan pikiran. Kebermaknaan (meaningfull) mempengaruhi ingatan, dalam arti bahwa semakian sesuatu keterangan atau informasi itu bermakna, maka semakin mudah pula keterangan tersebut dipahami (Prawiradilaga, 2008:18).

Manfaat aktivitas dalam belajar menurut Hamalik (2003) mengatakan bahwa: (1) siswa mencari berbagai pengalaman sendiri dan juga dapat secar langsung mengalami sendiri, (2) memupuk kerjasama yang harmonis di kalangan siswa sehingga memperlancar kerja kelompok-kelompok belajar, (3) siswa belajar dan bekerja berdasarkan minat dan kemampuan yang dimilikinya sendiri, (4) berbuat secara individual sehingga dapat mengembangkan semua aspek pribadi yang dimiliki siswa itu sendiri, (5) memupuk disiplin belajar dan suasana belajar yang demokratis kekeluargaan, musyawarah dan mufakat, (6) membina dan memupuk kerjasama antar sekolah, masyarakat, guru dan orang tua siswa, (7) pembelajaran dan belajar dilaksanakan secara realistik dan holistik, dan (8) suasana pembelajaran yang dilaksanakan guru baik di dalam maupun luar kelas menjadi lebih hidup dan menyenangkan.

Berdasarkan uraian di atas dapat disimpulkan bahwa proses pembelajaran lebih banyak dilakukan siswa sendiri, misalnya mencari/menentukan pengalaman sendiri, berbuat sendiri, memupuk kerjasama, disiplin dan suasana belajar menjadi hidup dan menyenangkan. Pada akhirnya, metode pemberian tugas merupakan 
prosedur mengajar yang menitikberatkan studi atau pengkajian secara individual, manipulasi objek-objek, dan eksperimen yang dilaksanakan oleh siswa sebelum mengambil kesimpulan (Hamalik, 2003).

Dalam proses pembelajaran yang berlangsung di dalam kelas, guru tidak akan menjelaskan dengan kata-kata (verbalisme) sebelum siswa menyadari akan pengertian atau konsep yang sedang dipelajarinya. Dalam metode ini siswa belajar melalui partisipasi aktif menemukan konsep-konsep dan prinsip-prinsip agar mudah memperoleh pengalaman sendiri. Richey, Klein, dan Nelson (2007), menyatakan bahwa hal apapun yang dipelajari siswa, maka ia harus mempelajarinya sendiri tidak ada seorang pun yang dapat melakukan untuknya. Dengan demikian, maka metode pemberian tugas ini merupakan komponen dari praktik pendidikan yang meliputi metode mengajar dengan memajukan cara belajar aktif, berorientasi pada proses, mengarahkan sendiri, mencari sendiri dan reflektif.

Definisi hasil belajar dijelaskan Dimyati dan Mudjiono (1999) yaitu hasil dari suatu interaksi tindak belajar dan tindak mengajar Sementara itu Djamarah dan Zain (2002) menjelaskan bahwa hasil belajar adalah penguasaan peserta didik terhadap bahan/materi pelajaran yang telah guru berikan ketika proses mengajar berlangsung.

Nurmawati (2016) menjelaskan hasil belajar merupakan segala prilaku yang dimiliki peserta didik sebagai akibat dari proses belajar yang ditempuhnya. Perubahan tersebut mencakup aspek tingkah laku secara menyeluruh baik aspek kognitif, afektif dan psikomotorik. Senada dengan penjelasan ini, Syah (2010) menjelaskan hasil belajar meliputi segenap ranah psikologis yang berubah sebagai akibat dari pengalaman dan proses belajar siswa baik yang berdimensi cipta, dan rasa maupun yang berdimensi karsa.

Sementara itu Bloom sebagaimana dikutip Rusmono (2012) menjelaskan hasil belajar meliputi tiga ranah yaitu: (1) ranah afektif meliputi tujuan-tujuan belajar yang berhubungan dengan memanggil kembali pengetahuan dan pengembangan kemampuan intelektual dan keterampilan, (2) ranah afektif meliputi tujuan-tujuan belajar yang menjelaskan perubahan sikap, minat, nilai-nilai dan pengembangan apresiasi serta penyesuaian, dan (3) ranah psikomotorik mencakup perubahan prilaku yang menunjukkan bahwa siswa telah mempelajari keterampilan manipulatif fisik tertentu.

Rohani dan Ahmadi (1995) menjelaskan bahwa penilaian hasil belajar bertujuan melihat kemajuan belajar siswa dalam hal penguasaan 
materi pengajaran yang telah dipelajarinya sesuai dengan tujuan-tujuan yang telah ditetapkan. Tujuan merupakan sasaran atau obyek yang akan dicapai. Sasaran atau obyek evaluasi hasil belajar adalah perubahan tingkah laku yang mencakup bidang kognitif, afektif dan psikomotor secara seimbang. Aspek-aspek tersebut sebaiknya dapat diungkapkan melalui penilaian tersebut. Dengan demikian dapat diketahui tingkah laku mana yang sudah dikuasai siswa dan mana tingkah laku yang belum dikuasai siswa.

\section{METODOLOGI PENELITIAN}

Penelitian dilakukan di Madrasah Tsanawiyah Negeri Tanah Jawa Simalungun. Metode penelitian yang digunakan adalah penelitian kuantitiatif korelasional. Populasi dalam penelitian ini adalah seluruh siswa kelas VIII yang terdiri dari 6 kelas dengan jumlah 172. Sampel sebesar 35\% dari siswa yang berjumlah 205 yaitu 71,75 dibulatkan 72 siswa yang diambil secara acak (random sample). Instrumen pengumpulan data yang digunakan adalah angket dan tes. Analisis data yang digunakan adalah korelasi dan regresi.

\section{HASIL PENELITIAN DAN PEMBAHASAN}

Temuan penelitian menunjukkan bahwa terdapat kontribusi kontribusi positif dan signifikan antara penerapan metode pembelajaran dengan hasil belajar siswa Madrasah Tsanawiyah Negeri Tanah Jawa Simalungun dengan angka korelasinya 0,354. Penerapan metode pembelajaran juga memberikan sumbangan yang efektif terhadap hasil belajar siswa Madrasah Tsanawiyah Negeri Tanah Jawa Simalungun dengan angkanya sebesar 9,90\%.

Data ini menjadikan peluang bagi guru untuk mengaktifkan penerapan metode pembelajaran yang lebih baik lagi agar terjadi peningkatan hasil belajar siswa Madrasah Tsanawiyah Negeri Tanah Jawa Simalungun. Penerapan metode pembelajaran yang dilakukan guru secara memadai akan melahirkan aktivitas belajar siswa Madrasah Tsanawiyah Negeri Tanah Jawa Simalungun yang diharapkan dapat mencapai hasil belajar yang maksimal.

Pembelajaran Fikih sebagai salah satu mata pelajaran yang diberikan kepada siswa memiliki ruang lingkup yang cukup luas dan mempunyai karakteristik yang berbeda dengan matapelajaran lainnya, karena materi ajar yang ada dalam matapelajaran Fikih terkait dengan ajaran agama yang tidak hanya dituntut penguasaan secara kognitif saja 
tetapi lebih dari itu sebagai ajaran agama maka diamalkan dalam kehidupan keseharian.

Pembelajaran dikatakan berhasil ditentukan oleh berbagai faktor, diantaranya adalah faktor yang berhubungan dengan penerapan metode pembelajaran yang dilakukan guru. Hasil belajar Fikih yang optimal dapat dicapai melalui berbagai upaya yang dilakukan guru salah satunya adalah penerapan metode pembelajaran yang lebih bermakna di mana melalui metode pembelajaran tersebut siswa mampu menemukan sendiri pengetahuan dan ketrampilan yang dibutuhkannya, bukan karena diberitahukan oleh guru saja tetapi siswa mampu mengkonstruksi sendiri pengetahuan dalam benaknya. Penerapan metode pembelajaran dalam proses pembelajaran menuntut adanya keterlibatan penuh dari siswa maupun guru baik secara mental dan emosional. Dengan adanya keterlibatan mental dan emosional dalam proses pembelajaran akan memungkinkan tercapainya tujuan-tujuan belajar serta diperolehnya hasil belajar yang efektif.

Guru diharapkan memiliki pengetahuan dan pemahaman mengenai metode pembelajaran dalam pelaksanaan pembelajaran sebab pengetahuan dan pemahaman mengenai metode pembelajaran penting sebagai salah satu upaya untuk memberikan pengalaman dan pencapaian tujuan belajar siswa yang optimal. Jadi untuk menentukan metode pembelajaran yang efektif dalam mengajarkan materi ajar diperkirakan dari kemungkinannya yang dapat membangkitkan keterlibatan mental siswa dalam belajar.

Metode pembelajaran yang tepat diterapkan di kelas diharapkan siswa benar-benar terlibat dalam kegiatan belajar dan memberikan lebih banyak kesempatan bagi siswa untuk memperoleh kesadaran dan mengembangkan konsep dirinya dengan lebih baik dan juga mengembangkan kemampuan individu. Siswa harus didorong untuk memecahkan masalah dalam kerja kelompok atau perorangan. Dalam hal ini, guru merupakan narasumber yang tugasnya memberikan bantuan yang diperlukan untuk menjamin dan mengarahkan siswa dalam mencapai tujuan pembelajaran yang ditetapkan.

Pembelajaran Fikih sebagai salah satu matapelajaran yang diberikan di sekolah dasar memiliki ruang lingkup yang cukup luas dan mempunyai karakteristik yang berbeda dengan matapelajaran lainnya, karena materi ajar yang ada dalam matapelajaran Fikih terkait dengan ajaran agama yang tidka hanya dituntut penguasaan secara kognitif saja tetapi lebih ajaran agama tersebut diamalkan dalam kehidupan 
keseharian. Oleh karena itu mencapai hal tersebut tentu saja membutuhkan keterampilan guru yang berbeda juga dalam membelajarkan siswa dalam mata pelajaran Fikih ini. Guru harus menggunakan metode pembelajaran yang efektif dan efisien agar pembelajaran dapat mencapai hasil yang diinginkan. Selain itu, tujuan pembelajaran akan mudah tercapai jika siswa termotivasi untuk belajar.

Aktivitas belajar siswa Madrasah Tsanawiyah Negeri Tanah Jawa Simalungun juga menunjukkan kontribusi positif dan signifikan dengan hasil belajar dengan besaran korelasi 0,473. Hal ini menunjukkan kategori kontribusi antara aktivitas belajar dengan hasil belajar siswa Madrasah Tsanawiyah Negeri Tanah Jawa Simalungun kategori sedang. Sumbangan efektif yang diberikan variabel aktivitas belajar terhadap hasil belajar sebesar 20,00\%. Data ini menjadikan peluang bagi guru untuk meningkatkan program atau kegiatan yang berkaitan dengan aktivitas belajar siswa Madrasah Tsanawiyah Negeri Tanah Jawa Simalungun.

Tercapainya hasil belajar siswa Madrasah Tsanawiyah Negeri Tanah Jawa Simalungun yang tinggi tidak dapat dilakukan dalam proses pembelajaran yang bersifat rutinitas saja. Siswa harus di tempatkan sebagai subjek belajar, bukan sebagai objek belajar. Sebagai subjek belajar, berarti siswa terlibat secara aktif dalam proses pembelajaran, di mana siswa diberikan ruang dan waktu yang seluas-luasnya untuk melakukan aktivitas belajarnya. Misalnya, siswa aktif berdiskusi, belajar mandiri, meringkas pelajaran, mencari informasi, melakukan penyelidikan, dan melakukan pembuktian-pembuktian.

Hal ini akan berdampak pada hasil belajar yang akan diperolehnya. Sebaliknya, apabila siswa di posisikan sebagai objek belajar, berarti siswa termasuk tidak aktif terlibat dalam proses pembelajaran, di mana ia hanya banyak mendengarkan apa yang disampaikan guru. Karena itu, kondisi demikian akan menyebabkan rendahnya hasil belajar.

Pembelajaran merupakan inti dari proses pendidikan secara keseluruhan, dengan guru sebagai pemegang peran utamanya. Dalam proses pembelajaran terdapat serangkaian perbuatan guru dan siswa atas dasar hubungan timbal balik yang berlangsung dalam situasi edukatif untuk mencapai tujuan tertentu. Interaksi atau hubungan timbal balik antara guru dan siswa inilah yang merupakan syarat utama berlangsungnya proses pembelajaran selain interaksi edukatif juga mempunyai terhadap proses pembelajaran tersebut. Dalam hal ini guru bukan hanya sebagai bahan penyampaian materi pelajaran, melainkan 
sebagai penyampai agar tercapainya hasil belajar dan sikap dalam diri siswa yang sedang belajar.

Tercapainya hasil belajar siswa yang tinggi tidak dapat dilakukan dalam proses pembelajaran yang bersifat rutinitas saja. Siswa harus di tempatkan sebagai subjek belajar, bukan sebagai objek belajar. Sebagai subjek belajar, berarti siswa terlibat secara aktif dalam proses pembelajaran, di mana siswa diberikan ruang dan waktu yang seluasluasnya untuk melakukan aktivitas belajarnya. Misalnya, siswa aktif berdiskusi, belajar mandiri, meringkas pelajaran, mencari informasi, melakukan penyelidikan, dan melakukan pembuktian-pembuktian. Hal ini akan berdampak pada hasil belajar yang akan diperolehnya. Sebaliknya, apabila siswa di posisikan sebagai objek belajar, berarti siswa termasuk tidak aktif terlibat dalam proses pembelajaran, di mana ia hanya banyak mendengarkan apa yang disampaikan guru. Karena itu, kondisi demikian akan menyebabkan rendahnya hasil belajar.

Metode pembelajaran yang digunakan guru akan dapat mempengaruhi tingkat pencapaian hasil belajar siswa. Penggunaan metode pembelajaran yang tepat dan sesuai dengan karakteristik siswa akan memberikan hasil belajar yang baik pula. Oleh karena itu tidaklah mudah bagi seorang guru untuk dapat menarik minat dan perhatian siswa dalam mempelajari materi ajar Pendidikan Agama Islam. Guru harus mampu menerapkan metode pembelajaran yang tepat untuk siswa yang memiliki karakteristik yang berbeda. Kurang mampunya guru mendesain dan melaksanakan metode pembelajaran yang sesuai dengan karakteristik siswa akan berakibat sulitnya siswa mencerna materi yang diberikan. Di samping itu, juga akan menimbulkan kebosanan dalam proses pembelajaran. Hal ini akan berdampak tidak tercapainya tujuan pembelajaran untuk memperoleh hasil yang efektif dan efisien.

Kedudukan metode pembelajaran dengan keberhasilan seseorang siswa dalam belajar sangat erat dan tidak bisa dipisahkan. Semakin bervariasi penerapam metode pembelajaran yang dilakukan guru maka siswa maka akan semakin besar pula upaya yang ia lakukan untuk mencapai keberhasilan belajarnya. Karena kemandirian dalam diri seseorang menjadi penggerak (motor) yang akan mengaktifkan seluruh enegeri yang ada termasuk kegiatan belajar. Dengan demikian, dapat dinyatakan bahwa kemandirian belajar memiliki hubungan positif dan signifikan dengan hasil belajar siswa.

Disamping itu proses pembelajaran kegiatan dan aktivitas guru yang paling menentukan dalam proses pembelajaran mengupayakan agar 
siswa memiliki pengetahuan tentang apa yang dipelajari. Selain itu adalah membangkitkan minat dan kemandirian siswa untuk mau belajar secara suka rela. Kegiatan ini merupakan hal terpenting yang harus dibangun pada tahap pendahuluan ini. Penciptaan kondisi yang demikian sangatlah penting dilakukan sebelum memulai pembelajaran, karena pada hakikatnya aktivitas belajar adalah aktivitas yang berhubungan dengan keadaan pisik dan mental seorang siswa.

Tugas utama yang harus dilakukan guru dalam pembelajaran adalah memperbanyak aktivitas siswa dalam belajar. Sebaliknya memperkecil ruang kepada guru alam aktivitas mengajar, karena dengan memperbanyak aktivitas belajar maka siswa akan lebih memahami apa yang ia pelajari, misalnya, mencatat, membuat ringkasan, menggarisbawahi, aktif bertanya dan menjawa pertanyaan dari guru, melakukan penyelidikan, mengumpulkan data, dan melakukan pengujian-pengujian. Dengan aktivitas-aktivitas belajar itu dimungkinkan hasil belajar akan menjadi lebih baik.

Demikian juga halnya dengan penerapan metode pembelajaran yang merupakan kekuatan dari luar (eksternal) dan dalam (internal) yang melandasi siswa dalam melakukan aktivitas-aktivitas belajarnya. Aktivitas belajar yang tinggi akan melahirkan sikap yang sungguh-sungguh dalam belajar yang ditandai dari ketekunan mengerjakan tugas-tugas yang diberikan guru, disiplin dengan waktu belajar, konsentrasi dalam belajar dan lain sebagainya. Apabila hal tersebut dilakukan secara benar dan konsisten akan berdampak pada meningkatnya hasil belajar yang diperoleh siswa.

Apabila dicermati lebih lanjut mengenai sumbangan efektif dari kedua variabel yaitu variabel penerapan metode pembelajaran dan aktivitas belajar terhadap hasil belajar siswa Madrasah Tsanawiyah Negeri Tanah Jawa Simalungun maka yang lebih besar memberikan konstribusinya adalah aktivitas belajar. Hal ini disebabkan karena hasil belajar ditentukan dengan adanya aktivitas belajar yang tinggi untuk melaksanakan tugas dan fungsinya yang melekat pada diri guru.

Penerapan metode pembelajaran dan aktivitas belajar secara bersama-sama menunjukkan hubungan yang positif dan signifikan dengan hasil belajar siswa Madrasah Tsanawiyah Negeri Tanah Jawa Simalungun dengan besaran korelasi 0,549 dan sumbangan efektif yang diberikan penerapan metode pembelajaran dan aktivitas belajar secara bersama-sama terhadap hasil belajar adalah 30,20\%. Hal ini bermakna 
bahwa masih terdapat lagi faktor-faktor yang dapat menunjang hasil belajar yang tidak dikaji dalam penelitian ini.

\section{SIMPULAN}

Simpulan penelitian adalah: (1) terdapat kontribusi positif dan signifikan antara penerapan metode pembelajaran dengan hasil belajar siswa Madrasah Tsanawiyah Negeri Tanah Jawa Simalungun. Artinya semakin tinggi dan positif penerapan metode pembelajaran maka semakin tinggi dan positif pula hasil belajar siswa dengan memberikan sumbangan yang efektif sebesar 9,90\%. Selanjutnya terdapat linearitas dan keberartian regresi variabel penerapan metode pembelajaran terhadap variabel hasil belajar yang dibuktikan dengan adanya persamaan garis regresi $\hat{Y}=71,60+0,23 X_{1}$ yang bermakna terjadi peningkatan pada satu skor penerapan metode pembelajaran akan meningkat setiap 0,23 skor pada hasil belajar sehingga hasilnya dapat dipertanggungjawabkan, (2) terdapat kontribusi positif dan signifikan antara aktivitas belajar dengan hasil belajar siswa Madrasah Tsanawiyah Negeri Tanah Jawa Simalungun. Sumbangan yang efektif sebesar 20,00\%, hal ini dapat diartikan bahwa variasi yang terjadi pada variabel aktivitas belajar sebesar 20,00\% dapat diprediksi dalam meningkatkan hasil belajar. Selanjutnya terdapat terdapat linearitas dan keberartian regresi variabel aktivitas belajar terhadap variabel hasil belajar yang dibuktikan dengan adanya persamaan garis regresi $\hat{Y}=68,96+0,28 X_{2}$ yang bermakna terjadi peningkatan pada satu skor aktivitas belajar akan meningkat setiap 0,28 skor pada hasil belajar sehingga hasil dapat dipertanggungjawabkan, dan (3) terdapat kontribusi positif dan signifikan secara bersama-sama antara penerapan metode pembelajaran dan aktivitas belajar dengan hasil belajar siswa Madrasah Tsanawiyah Negeri Tanah Jawa Simalungun. Sumbangan efektif sebesar 30,20\%. Hal ini bermakna bahwa 30,20\% dari variasi yang terjadi hasil belajar dapat diprediksi oleh kedua variabel bebas tersebut. Penerapan metode pembelajaran dan aktivitas belajar secara bersamasama dapat meningkatkan hasil belajar dengan garis linearitas $\hat{Y}=138,80$ $+0,18 X_{1}+0,25 X_{2}$.

\section{REKOMENDASI}

Rekomendasi yang dapat disampaikan adalah: (1) kepada Kepala Madrasah untuk memberikan petunjuk kepada guru untuk menerapkan metode pembelajaran secara kontiniu melalui rapat koordinasi dan kunjungan kelas serta memberikan kesempatan kepada guru untuk 
mengembangkan potensinya untuk mengikuti pendidikan ke jenjang lebih tinggi maupun mengikuti pelatihan, (2) Kepada guru untuk kiranya dapat menerapkan metode peembelajaran yang bervariasi karena melalui hal tersebut diharapkan dapat meningkatkan aktivitas belajar siswa yang pada gilirannya dapat meningkatkan hasil belajar siswa, dan (3) Kepada peneliti lain bahwa penelitian ini perlu ditindak lanjuti khususnya yang berkaitan dengan variabel-variabel berbeda yang turut memberikan sumbangan terhadap hasil belajar.

\section{DAFTAR PUSTAKA}

Agung, Iskandar. (2010) Meningkatkan Kreativitas Pembelajaran Bagi Guru. Jakarta: Bestari Buana Murni.

Daulay, Haidar Putra. (2016) Pemberdayaan Pendidikan Agama Islam di Sekolah. Jakarta: Kencana.

Dimyati dan Moedjiono. (1999) Belajar dan Pembelajaran, Jakarta: Rineka Cipta.

Djamarah, Syaiful Bahri dkk, (2002). Strategi Belajar Mengajar. Jakarta: Rineka Cipta.

Hamalik, Oemar. (2003) Proses Belajar Mengajar. Jakarta: Bumi Aksara.

Hasibuan, JJ. Dan Moedjiono. (2004) Proses Belajar Mengajar. Bandung: Remaja Rosdakarya.

Nasution, S. (2005) Berbagai Pendekatan Dalam Proses Belajar Mengajar. Jakarta: Bumi Aksara.

Nata, Abuddin. (2014) Perspektif Islam Tentang Strategi Pembelajaran. Jakarta: Kencana.

Nurmawati. (2016) Evaluasi Pendidikan Islami. Bandung: Citapustaka.

Prawiradilaga. Dewi. S. (2008) Prinsip Desain Pembelajaran. Jakarta: Universitas Negeri Jakarta.

Richey, R.C; Klein, James D \& Nelson, W.A. (2007) Develomental Research: Studies of Instructional Design and Development. Handbook of Research for Educational Communication and Technology. New York: MacMillan Simon \& Schuster.

Rusmono, (2012) Strategi Pembelajaran Dengan Problem Based Learning Itu

Perlu Untuk Meningkatkan Porfesionalitas Guru. Bogor: Ghalia Indonesia

Salim. (2018) Metodologi Penelitian Kuantitatif. Bandung:Citapustaka Media. Sanjaya, Wina. (2014) Strategi Pembelajaran, Berorientasi Standar Proses Pendidikan. Jakarta: Prenada Media Group. 
Slameto. (2003) Belajar dan Faktor-Faktor Yang Mempengaruhinya. Jakarta: Rineka Cipta.

Smaldino, Sharon E., Lowther, Deborah L. dan Russell, James D. (2008) Instructional Technology and Media for Learning. Ninth Edition. New Jersey: Pearson Prentice Hall.

Soetomo. (2003) Dasar-Dasar Interaksi Belajar Mengajar. Surabaya. Usaha Nasional.

Sudjana, Nana. (2002) Dasar-Dasar Proses Belajar Mengajar. Jakarta; Sinar Baru Algensindo.

Syah, Muhibbin. (2010) Psikologi Pendidikan Dengan Pendekatan Baru. Bandung: Remaja Rosdakarya.

Usman, M. Basyiruddin. (2002) Metodologi Pembelajaran Agama Islam. Jakarta: Ciputat Pers. 